\title{
Nitric Oxide Inhibits Topoisomerase II Activity and Induces Resistance to Topoisomerase II-Poisons in Human Tumor Cells
}

\author{
Ashutosh Kumar ${ }^{\mathrm{a}}$, Marilyn Ehrenshaft ${ }^{\mathrm{a}}$, Erik J. Tokar ${ }^{\mathrm{b}}$, Ronald P. Mason ${ }^{\mathrm{a}}$, and Birandra K. \\ Sinha ${ }^{a,{ }^{*}}$ \\ ammunity, Inflammation and Disease Laboratory, National Institutes of Environmental Health \\ Sciences, NIH, Research Triangle Park, North Carolina, USA \\ bNational Toxicology Program, National Institutes of Environmental Health Sciences, $\mathrm{NIH}$, \\ Research Triangle Park, North Carolina, USA
}

\section{Abstract}

Background-Etoposide and doxorubicin, topoisomerase II poisons, are important drugs for the treatment of tumors in the clinic. Topoisomerases contain several free sulfhydryl groups which are important for their activity and are also potential targets for nitric oxide ( $\left.{ }^{\circ} \mathrm{NO}\right)$-induced nitrosation. ${ }^{\circ} \mathrm{NO}$, a physiological signaling molecule nitrosates many cellular proteins, causing altered protein and cellular functions.

Methods-Here, we have evaluated the roles of ${ }^{\circ} \mathrm{NO} /{ }^{\circ} \mathrm{NO}$-derived species in the activity stability of topo II both in vitro and in human tumor cells, and in the cytotoxicity of topo II-poisons, etoposide and doxorubicin.

Results-Treatment of purified topo IIa with propylamine propylamine nonoate (PPNO), an ${ }^{\circ} \mathrm{NO}$ donor, resulted in inhibition of both the catalytic and relaxation activity in vitro, and decreased etoposide-dependent cleavable complex formation in both human HT-29 colon and MCF-7 breast cancer cells. PPNO treatment also induced significant nitrosation of topo IIa protein in these human tumor cells. These events, taken together, caused a significant resistance to etoposide in both cell lines. However, PPNO had no effect on doxorubicin-induced cleavable complex formation, or doxorubicin cytotoxicity in these cell lines.

Conclusion-Inhibition of topo II function by ${ }^{\circ} \mathrm{NO} /{ }^{\circ} \mathrm{NO}-$ derived species induces significant resistance to etoposide, without affecting doxorubicin cytotoxicity in human tumor cells.

General Significance-As tumors express inducible nitric oxide synthase and generate significant amounts of ${ }^{\circ} \mathrm{NO}$, modulation of topo II functions by ${ }^{\circ} \mathrm{NO} /{ }^{\circ} \mathrm{NO}-$ derived species could render tumors resistant to certain topo II-poisons in the clinic.

*Corresponding author: Dr. Birandra K. Sinha at Immunity, Inflammation and Disease Laboratory, National Institutes of Environmental Health Sciences, NIH, Research Triangle Park, North Carolina, USA. Phone: 919-541-4751; sinha1 @ niehs.nih.gov.

Publisher's Disclaimer: This is a PDF file of an unedited manuscript that has been accepted for publication. As a service to our customers we are providing this early version of the manuscript. The manuscript will undergo copyediting, typesetting, and review of the resulting proof before it is published in its final citable form. Please note that during the production process errors may be discovered which could affect the content, and all legal disclaimers that apply to the journal pertain. 


\section{Keywords}

Nitric oxide; Topoisomerase II; VP-16; Doxorubicin; Cytotoxicity; Resistance

\section{Introduction}

Topoisomerases constitute an important class of nuclear enzymes responsible for maintaining the topology of DNA and are involved in DNA repair, transcription, replication and segregation of chromosomes [1-5]. Inhibition and/or interference with topoisomerase functions has been shown to cause cell death $[1,3,5-8]$. The clinically active anticancer drugs etoposide (VP-16) and doxorubicin (DOX) act as topo II poisons and induce accumulations of enzyme-linked double-strand breaks that are highly cytotoxic to cells [6, 8]. Cytotoxicity of these drugs also depend upon other factors including metabolic activation [9-11], the presence of p-glycoprotein [12, 13], cellular topo II levels [14, 15] and free radical formation [16]. Furthermore, the presence of functional p53 protein (wtp53) is an important determinant of the sensitivity to many anticancer drugs as it responds appropriately to DNA damage, repair, and commitment to undergo apoptosis [17].

Mammalian cells express two isoforms of topo II (topo IIa and topo II $\beta$ ) $[18,19]$. Topo IIa is highly expressed in replicating cells and is a cell cycle-dependent enzyme necessary for cell survival. In contrast, the expression of topo II $\beta$ is not cell cycle-dependent and is expressed at constant levels throughout the cell cycle. Topo II $\beta$ has been reported to play an important role in transcription $[20,21]$ and may have implications for the induction of secondary leukemia following VP-16 treatment in children [21-24].

Nitric oxide ( $\left.{ }^{\circ} \mathrm{NO}\right)$ is an important signaling molecule in many biological systems. Studies have shown that the effects of ${ }^{\circ} \mathrm{NO}$ are biphasic: At low concentrations $(<50 \mathrm{nM})$ it promotes tumor growth, while at higher concentrations $(>300 \mathrm{nM})$, it causes DNA damage and leads to cell death [25-28]. In vivo, ${ }^{\circ} \mathrm{NO}$ is formed from L-arginine by nitric oxide synthase (NOS). Three forms of NOS have been identified, including neuronal (nNOS), endothelial (eNOS) and a $\mathrm{Ca}^{2+}$-independent inducible isoform (iNOS). High expression of iNOS and increased production of ${ }^{\circ} \mathrm{NO}$ have been described in many human tumors, including breast, prostate and colorectal cancers [29-32]. Furthermore, ${ }^{\circ} \mathrm{NO}$ has been implicated in cancer progression, tumor aggressiveness and poor prognosis in the clinic [26]. A poor clinical outcome may be related to ${ }^{\mathrm{NO}}$-induced rapid tumor growth, resulting in hypoxia, nutrient deprivation, poor drug delivery, and selection for drug-resistant tumor cells. Our recent studies have clearly shown that ${ }^{\circ} \mathrm{NO}$, whether generated intracellularly in human melanoma cells or generated via NO-donors, reacts rapidly with VP-16 rendering it inactive against tumor cells in vitro [33, 34]. More recently, we have shown that generation of ${ }^{\bullet} \mathrm{NO}$ via NOdonor induces significant resistance in human breast MCF-7 cancer cells to camptothecin, a topo I-poison [35]. Furthermore, iNOS and ${ }^{\mathrm{NO}}$ have been shown to play significant roles in induction of resistance to taxol in certain aggressive estrogen receptor negative human breast cancer cells in vitro and in vivo [36].

A major pathway for ${ }^{\circ} \mathrm{NO}$-dependent cellular signaling has been proposed to be $\mathrm{S}$ nitrosation (also known as S-nitrosylation) of proteins resulting from reactions of cysteine 
residues with reactive nitrogen species such as $\mathrm{NO}^{+},{ }^{-} \mathrm{NO}_{2}$ or $\mathrm{N}_{2} \mathrm{O}_{3}$ [37-39]. Increased intracellular generation of ${ }^{\circ} \mathrm{NO} /{ }^{\circ} \mathrm{NO}$-related species has been shown to modulate functions of various important cellular proteins, including hypoxia inducible factor (HIF 1), prolyl hydroxylase (PHD2) enzyme, and the bcl2 family of proteins, and to cause activation of certain caspases [40-45]. "NO-dependent nitrosation of free cysteine residue also affects the stability and up-regulation of protein expression via posttranslational modifications by affecting the proteasomal degradation pathway [41]. Topo I and II contain several redoxactive cysteines, and modification of reactive SH groups in topo II leads to the inhibition of the catalytic activity of the protein [46].

Because tumors express iNOS, ${ }^{\circ} \mathrm{NO}$ is continuously generated intracellularly. Furthermore, during inflammation, large amounts of ${ }^{\circ} \mathrm{NO}$ are formed that diffuse into tumor tissue/cells and could affect the stability and/or activity of proteins. Therefore, it is possible that the activity/stability of topo II can be modified by ${ }^{\circledR} \mathrm{NO}$ as we reported for topo I [35]. Herein, we have used breast cancer MCF-7 cells and colon cancer HT-29 cells to study the effects of ${ }^{\circ} \mathrm{NO}$ (generated via an NO-donor) on the stability of topo II protein and to examine the cytotoxic effects of topo II-poisons (VP-16, and DOX) in these tumor cell lines. Our results show that ${ }^{\circ} \mathrm{NO} /{ }^{\circ} \mathrm{NO}-$ related species inhibit the catalytic and relaxation activity of topo II. In addition, we found that these effects of ${ }^{\circ} \mathrm{NO} /{ }^{\circ} \mathrm{NO}$-related species on topo II result in resistance to VP-16 in both the HT-29 and MCF-7 tumor cell lines. In contrast, there were no significant effects on the activity of DOX in either cell line.

\section{Materials and Methods}

\subsection{Chemicals and Antibodies}

Etoposide (VP-16,213) and Doxorubicin were gifts of the Drug Synthesis and Chemistry Branch, Developmental Therapeutic Program of NCI, NIH. Purified topo IIa, supercoiled pHOT1 DNA, kDNA, and SDS/KCl precipitation assay kits were obtained from Topogen (Port Orange, FL). Primary antibodies for the detection of topo IIa was obtained from Abcam, Cambridge, MA. The nitric oxide donor, propylamine propylamine nonoate (PPNO), was obtained from Cayman Chemicals (Ann Arbor, MI). The nitric oxide donor, Snitrosoglutathione (GSNO) was purchased from Santa Cruz Biotechnology, Inc (Dallas, TX). A stock solution of PPNO or GSNO was prepared in $0.2 \mathrm{~N} \mathrm{NaOH}$ and was stored at $-80^{\circ} \mathrm{C}$. Stock solutions of DOX (in $\mathrm{H}_{2} \mathrm{O}$ ), VP-16 (in DMSO) were prepared and stored at $-80^{\circ} \mathrm{C}$. Fresh drug solutions prepared from stock solutions were used in all experiments.

\subsection{Cell Culture and Cytotoxicity Studies}

Human breast MCF-7 and colon cancer HT-29 cell lines (ATCC, Rockville, MD) were grown in Phenol Red-free RPMI media supplemented with $10 \%$ fetal bovine serum and antibiotics. MCF-7 cells and HT-29 cells (doubling times of about $24 \mathrm{~h}$ ) were routinely used for 15-20 passages, after which the cells were discarded and a new cell culture was started from fresh, frozen stock. For the treatment with PPNO $(25-100 \mu \mathrm{M})$, cells were plated in RPMI media containing 1.0\% FBS without antibiotics. After the prescribed treatment period $(0-6 \mathrm{~h})$, the medium was changed to a regular medium containing $10 \%$ FBS and antibiotics. 
The cytotoxicity studies were carried out with a cell growth inhibition assay. For the cell count-based growth inhibition studies, 150,000-200,000 cells/well were plated in $2 \mathrm{ml}$ of complete medium onto a 6-well plate (in triplicate) and allowed to attach for $18 \mathrm{~h}$. The medium was removed and fresh warm medium $(2 \mathrm{ml})$ containing $1 \%$ FBS without antibiotics and $200 \mu \mathrm{l}$ of PBS (pH 7.0) was added. Cells were treated with PPNO $(100 \mu \mathrm{M})$ for $6 \mathrm{~h}$, followed by the addition of various concentrations of drugs (VP-16 or DOX), and were incubated for $48 \mathrm{~h}$ in the complete medium. DMSO was included as the vehicle control. Cells were trypsinized, and the numbers of surviving cells were determined by counting the cells in a cell counter (Beckman, Brea, CA). We used PPNO as our ${ }^{\circ} \mathrm{NO}$ donor because it has a short half-life ( $15 \mathrm{~min}$ at $\left.37^{\circ} \mathrm{C}, \mathrm{pH} 7.0\right)$, and found PPNO to be the least toxic to cells compared to various other ${ }^{\circ} \mathrm{NO}$-donors (e.g., diproylenetriamine nonoate). Even at $100 \mu \mathrm{M}$, only $10-15 \%$ of cells were found to be dead after $48 \mathrm{~h}$ of PPNO exposure.

\subsection{Effects of ${ }^{`} \mathrm{NO}$ on Topoisomerase lla Activity}

Measurements of the catalytic and relaxation activities for topo IIa were carried out as described previously [47, 48]. Briefly, topo IIa catalytic activity was determined by incubating $0.4 \mu \mathrm{g}$ kDNA with topo IIa (2 and 5 Units) in the presence or the absence of $25-$ $100 \mu \mathrm{M}$ PPNO in topo II buffer in the presence of ATP for $30 \mathrm{~min}$ at $37^{\circ} \mathrm{C}$. In some experiments, topo II was incubated with PPNO without DNA for $10 \mathrm{~min}$ at $37^{\circ} \mathrm{C}$, kDNA added, and the mixture incubated for an additional $20 \mathrm{~min}$. The reaction was stopped by adding stop buffer (10\% SDS) as described. The effects of ${ }^{\circ} \mathrm{NO}$ on the relaxation activity of topo IIa were similarly examined by using pHOT DNA ( $0.4 \mu \mathrm{g} /$ incubation) with 5 and $10 \mathrm{U}$ of topo IIa in the presence of $100 \mu \mathrm{M}$ PPNO as described previously.

\subsection{SDS-KCI Precipitation Assay}

The formation of covalent topo II/DNA complexes in HT-29 and MCF-7 cells with VP-16 under various conditions was quantitated by the SDS- $\mathrm{KCl}$ precipitation assay as described by Liu et al. [49]. Briefly, the DNA of cells growing in the logarithmic phase $\left(1 \times 10^{5}\right.$ cells/ $\mathrm{ml}$ ), seeded in triplicate in six-well plates, was labeled with [methyl- ${ }^{3} \mathrm{H}$ ]-thymidine $(1.0 \mu \mathrm{ci}$, 20Ci/mmol; Perkin-Elmer, Waltham, MA) for 18-24 h. Cells were washed twice with medium, and various concentrations of drugs (VP-16 dissolved in DMSO, or DOX, dissolved in doubly distilled water) were added and incubated for $1 \mathrm{~h}$. PPNO when used was present for $6 \mathrm{~h}$ before the addition of drugs. Cells were washed with PBS $(2 \mathrm{x})$ and lysed with $1 \mathrm{ml}$ of prewarmed lysis solution (Topogen). After lysis and shearing of DNA, DNAdrug-topo II-complexes were precipitated with $\mathrm{KCl}$. The precipitate was collected by centrifugation, and washed extensively $(4 \mathrm{x})$ with the washing solution (Topogen) according to the manufacturer's instructions. The radioactivity was counted in a scintillation counter after adding $5 \mathrm{ml}$ of scintillation fluid. PPNO alone had no significant effect on SDS-KCl precipitate formation.

\subsection{Western Blot Assay}

The Western Blot analyses for topo IIa was carried out with standard methods, and samples (40 $\mu \mathrm{g}$ of total protein) were electrophoresed under reducing conditions on 3-8\% Trisacetate gels (Novex, Life Technologies, Carlsbad, CA) for 50 minutes at 200 volts. After electrophoresis, proteins were transferred onto nitrocellulose membranes and probed with 
anti-topo IIa, and anti-beta actin antibodies. An Odssey infrared imaging system (Li-Cor Biosciences, Lincoln, NE) was used to acquire images.

\subsection{Real-Time Reverse Transcription-Polymerase Chain Reaction}

RT-PCR analysis was carried out as described previously [50] to examine gene expression levels in tumor cell lines following isolation of total RNA using TRIzol reagent (Invitrogen, Carlsbad, CA). Total RNA was purified with RNeasy mini kit columns (Qiagen, Valencia, CA) according to protocols from the manufacturers. Purified RNA was reverse transcribed to cDNA with the use of MuLV reverse transcriptase (Applied Biosystems, Foster City, CA) and oligo-dT primers. Primers were designed with the use of Primer Express 3.0 software (Applied Biosystems).

\subsection{Confocal Microscopy for Nitrosation of Topoisomerase II in Tumor Cells}

$1 \times 10^{5}$ cells were plated for $18 \mathrm{~h}$ at $37^{\circ} \mathrm{C}$ in culture plates on glass coverslips. The media was removed and replaced with fresh media and treated with $100 \mu \mathrm{M}$ PPNO or $500 \mu \mathrm{M}$ GSNO for $18 \mathrm{~h}$. To investigate the extent of nitrosation and co-localization of S-nitrosated adducts with topo I following PPNO and GSNO treatment, the cells were fixed with $4 \%$ paraformaldehyde for 15 minutes at room temperature, washed twice for 5 minutes, permeablized for 5 minutes with $0.5 \%$ Triton X-100, and washed twice for 5 minutes. After blocking with 4\% fish gelatin in PBS (pH 7.4) for $2 \mathrm{~h}$ at room temperature, the cells were incubated with rabbit anti-S-nitrosylated cysteine igG (diluted 1:2000) and mouse anti-topo IIa (diluted 1:2000) for $2 \mathrm{~h}$, followed by secondary anti-rabbit Alexa Fluor 488 and antimouse Alexa Fluor 568 antisera (both diluted 1:1000) for $1 \mathrm{~h}$. Coverslips containing cells were washed four times and mounted on glass slides using Prolong Gold anti-fade reagent. Confocal images were taken with a Zeiss LSM 510-UV Meta microscope (Carl Zeiss Inc., Oberkochen, Germany) using a Plan-NeoFluar 40X/1.3 Oil DIC objective with zoom 3. The $488 \mathrm{~nm}$ line from an Argon laser was used for producing polarized light for fluorescence excitation of the Alexa Fluor 488 secondary antibody. All images were acquired with equal excitation power (5\%) and identical detection gain (532 volts).

Statistical Analysis-Data are presented as means \pm SEM of at least three independent experiments and are considered significant when $\mathrm{p} \leq 0.05$. Statistical analysis was performed using a paired Student's t-test. $* * * * *$ and $*$ denote $\mathrm{p}$ values $<0.001,0.005$, and 0.05 , respectively.

\subsection{RESULTS}

\subsection{Effects of ${ }^{\circ} \mathrm{NO}$ on the Catalytic Activity of Topo lla}

Using purified topo IIa, we examined the effect of ${ }^{\circ} \mathrm{NO}$ (generated via the NO-donor, PPNO) on the catalytic activity of the enzyme. As shown in Fig. 1A, ${ }^{\circ} \mathrm{NO}$ significantly inhibited the catalytic activity as examined by decatenation of kDNA induced by 2 units of topo IIa. Under these conditions, ${ }^{\circ} \mathrm{NO}$ treatment resulted in the formation of various nicked open circular kDNA (NC) in addition to closed circular kDNA (CC) and the undecatenated DNA seen at the origin (ORI) of the gel. PPNO treatment was also effective in inhibiting decatenation reactions catalyzed by 5 units of the enzyme as seen by the undecatenated 
DNA seen at the origin of the gel. Lower concentrations of PPNO were less effective; however, significant inhibition was still observed with 2 units of the enzyme (not shown). PPNO alone had no effect on kDNA. It is interesting to note that when topo IIa was preincubated with PPNO for $10 \mathrm{~min}$, its catalytic activity was significantly more inhibited (Fig. 1A, lanes 6 and 7), suggesting that some of the cysteine SH groups in topo II bound to DNA were not good substrates for reaction with ${ }^{\circ} \mathrm{NO} /{ }^{\circ} \mathrm{NO}$-derived species. Alternatively, it is possible that modified/reacted topo IIa does not bind to kDNA and, thus, is unable to carry out decatenation reactions.

\subsection{Effect of ${ }^{*} \mathrm{NO}$ on the DNA Relaxation Activity of Topo Ila}

The effect of PPNO on the relaxation activity of topo IIa was determined using supercoiled pHOT DNA in the presence of ATP as described previously [47, 48]. The data presented in Fig. 1B clearly show that ${ }^{\circ} \mathrm{NO}$ effectively inhibits relaxation induced by topo IIa (5 units/ incubation), while relaxation induced by 10 units of the enzyme is only marginally inhibited. However, preincubation of topo IIa with PPNO completely inhibited topo II-induced relaxation, similar to the results observed with the catalytic activity. These observations would suggest that when topo II is bound to DNA, the SH group of cysteine in topo II is not accessible for modification with ${ }^{\circ} \mathrm{NO} /{ }^{\circ} \mathrm{NO}-$ derived species. Alternatively, modified topo IIa may not bind to DNA to induce relaxation.

\subsection{Cytotoxicity and DNA Damage Studies with VP-16}

We next evaluated whether ${ }^{\circ} \mathrm{NO}$ treatment of tumor cells also results in altered sensitivity to VP-16 in tumor cells. In HT-29 cells, PPNO significantly decreased VP-16 cytotoxicity (Fig. $2 \mathrm{~A}$ ), suggesting that ${ }^{\circ} \mathrm{NO}$ and/or its related species also affected topo II activity in tumor cells.

This was further confirmed using the SDS-KCl precipitation assay in HT-29 cells. Data depicted in Fig. 2B show that ${ }^{\circ} \mathrm{NO}$ or ${ }^{\circ} \mathrm{NO}-$ related species significantly decreased the activity

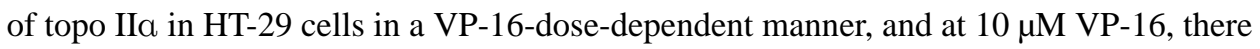
was about a $50 \%$ decrease in SDS-KCl precipitate formation in the presence of PPNO. Taken together, these studies suggest that ${ }^{\circ} \mathrm{NO} /{ }^{\circ} \mathrm{NO}-$ related species do inactivate topo II protein, and the enzymatic function of the modified topo II is significantly compromised.

We also carried out VP-16 cytotoxicity studies in human breast MCF-7 cancer cells to evaluate whether this inhibition of topo II activity by ${ }^{\circ} \mathrm{NO} /{ }^{\circ} \mathrm{NO}-$ related species would also modulates VP-16 cytotoxicity in other tumor cell lines. Data presented in Fig. 2C clearly show that ${ }^{\circ} \mathrm{NO} /{ }^{\circ} \mathrm{NO}-$ related species significantly affected VP-16 cytotoxicity and pretreatment of MCF-7 cancer cells with $100 \mu \mathrm{M}$ PPNO resulted in a 10-fold increased resistance to $\mathrm{VP}-16$, suggesting that ${ }^{\circ} \mathrm{NO} /{ }^{\circ} \mathrm{NO}-$ related species-induced inhibition of topo II can significantly affect VP-16 cytotoxicity in other tumor cells, e.g., MCF-7 cells.

To determine whether this decrease in VP-16 cytotoxicity in MCF-7 cells is related to differential formation of DNA-topo II cleavable complexes following PPNO $(100 \mu \mathrm{M})$ treatment in the presence of VP-16, the formation of cleavable complexes was examined using the SDS- $\mathrm{KCl}$ precipitation assay. Data in Fig. 2D clearly show that there was a significant decrease in the formation of DNA-topo II-VP-16 cleavable complexes in the 
presence of PPNO in MCF-7 cells. This would suggest that the difference in VP-16 cytotoxicity is due to initial topo II-mediated DNA damage in the presence of PPNO.

\subsection{Cytotoxicity and DNA Damage Studies with DOX}

Because one of the mechanisms of DOX-dependent tumor cell killing is due to its interactions with topo II, we also evaluated its cytotoxicity in both HT-29 and MCF-7 cell lines. Data presented in Fig. 3A and C clearly shows that PPNO had no significant effects on DOX cytotoxicity in either HT-29 or MCF-7 cells. We next examined effects of PPNO on cleavage complex formation in the presence of PPNO and DOX. In contrast to VP-16, no significant effects were observed with PPNO on DOX-induced SDS-KCl precipitate formation in either MCF-7 or HT-29 tumor cell lines (Fig. 3B and D).

\subsection{Effects of 'NO on the Topo II Protein}

Because ${ }^{\circ} \mathrm{NO} /{ }^{\circ} \mathrm{NO}$-related species have been reported to modulate both the activity and stability of various proteins, we examined whether PPNO treatment would affect the cellular levels of topo II proteins in a way that could account for the resistance observed with VP-16. No significant effects were observed in the cellular levels of topo IIa in either MCF-7 or HT-29 cells following PPNO treatment (Fig. 4). Furthermore, there were no significant differences at the transcript levels (mRNA) following PPNO treatment for topo IIa in these cell lines (Fig. 4).

\subsection{S-Nitrosation of Topoisomerase II}

Because ${ }^{\circ} \mathrm{NO} /{ }^{\circ} \mathrm{NO}$-related species are known to nitrosate $\mathrm{SH}$ groups, we used confocal microscopy studies to investigate whether PPNO treatment resulted in nitrosation of topo II. As shown (Fig. 5A), PPNO treatment caused significant nitrosation of the cysteine residues of topo IIa in MCF-7 tumor cells as detected using confocal microscopy. Similarly, GSNO, another NO donor, also significantly induced nitrosation of topo IIa protein in MCF-7 breast tumor cells. S- Nitrosated topo IIa proteins were also detected in HT-29 cells; however, significantly less of nitrosated topo II were observed in HT-29 tumor cells (Fig. 5B) compared to MCF-7 cells.

\subsection{DISCUSSION}

We have been studying the effects of ${ }^{\circ} \mathrm{NO} /{ }^{\circ} \mathrm{NO}-$ related species (both exogenously via an NO-donor and formed intracellularly in tumor cells) on the pharmacology of anticancer drugs and the mechanism of resistance to various topoisomerase-poisons. We have previously shown that ${ }^{\circ} \mathrm{NO} /{ }^{\circ} \mathrm{NO}-$ related species chemically react with $\mathrm{VP}-16$ and produce non-cytotoxic products, resulting in a significant resistance to VP-16 in tumor cells [33, 34]. We have also shown that $\mathrm{S}$-nitrosation resulting from reactions of cysteine residues with ${ }^{\circ} \mathrm{NO} /{ }^{\circ} \mathrm{NO}-$ related species results in the modification of protein-SH groups of topo I, causing the protein to undergo proteosomal degradation [35] in both the HT-29 and MCF-7 cancer cell lines. This reaction of protein $\mathrm{SH}$ has been postulated to involve various reactive species generated from ${ }^{\circ} \mathrm{NO}$ as shown below, which also results in protein dimerization and/or oxidation [38]. S-nitrosation can take place via the reaction of nitrosinium ion $\left(\mathrm{NO}^{+}\right)$ generated from $\mathrm{N}_{2} \mathrm{O}_{3}$ formed from ${ }^{\circ} \mathrm{NO}$ and ${ }^{\circ} \mathrm{NO}_{2}$ :

Biochim Biophys Acta. Author manuscript; available in PMC 2017 July 01. 


$$
\mathrm{NO}^{+}+\mathrm{RS}^{-} \rightarrow \mathrm{RSNO} \text { (nitrosation) }
$$

Alternatively,

$$
\begin{gathered}
2 \bullet \mathrm{NO}+\mathrm{O}_{2} \rightarrow 2 \bullet \mathrm{NO}_{2} \\
\mathrm{RSH}+\mathrm{NO}_{2} \rightarrow \mathrm{RS} \bullet \rightarrow \mathrm{RS}-\mathrm{RS}(\text { dimerization) } \\
\mathrm{RS}^{\bullet} \cdot{ }^{\bullet} \mathrm{NO} \rightarrow \mathrm{RSNO}(\text { nitrosation) } \\
\mathrm{RS}^{\bullet}+\mathrm{O}_{2} \rightarrow \mathrm{RSOOH} \text { (oxidation) }
\end{gathered}
$$

In the present study, we examined the effects of ${ }^{\circ} \mathrm{NO} /{ }^{\circ} \mathrm{NO}-$ related species generated via PPNO, an NO-donor, on topo II and certain topo II-poisons used clinically (i.e., VP-16 and DOX) to treat human tumors. While VP-16 undergoes extensive metabolism, catalyzed by cytochrome P450 and peroxidases, to form reactive o-quinone [9-11], the mechanism of cytotoxicity of VP-16 is considered to be due exclusively to its interactions with topo II. The mechanism of resistance of VP-16 involves both overexpression of p-glycoprotein [12, 13] and decreases in the cellular target protein and/or its decreased activity as low levels of topo II protein are correlated with VP-16 resistance [14, 15]. Here we used low concentrations of an ${ }^{\circ O}$-donor to mimic the physiological conditions of human tumors that express high levels of iNOS and/or contain infiltrating macrophages to show that the activity of topo II, an important cellular target of various clinically active anticancer agents, is significantly compromised, resulting in resistance to these drugs.

Our in vitro studies with purified topo IIa clearly show that treatment with ${ }^{\circ} \mathrm{NO} /{ }^{\circ} \mathrm{NO}$-derived species results in inhibition of both the catalytic and relaxation activity of topo IIa. The inhibition of topo II activities results from the reactions of free sulfhydryl groups (or other reactive groups in topo II) with ${ }^{\circ} \mathrm{NO} /{ }^{\circ} \mathrm{NO}-$ related species in vitro and in cells. A number of drugs are known to react with -SH groups of topo II, causing inhibition of its functions [5153]. Significant S-nitrosation of topo IIa was detected in MCF-7 breast tumor cells in the presence of PPNO and GSNO, a natural reservoir for ${ }^{\circ} \mathrm{NO}$ in cells and in vivo. In contrast, only a small amount of nitrosation of topo II-SH groups was observed in HT-29 tumor cells in the presence of either PPNO or GSNO. These studies strongly indicate that -SH groups of topo IIa protein is amenable to $\mathrm{S}$-nitrosation by ${ }^{\circ} \mathrm{NO} /{ }^{\circ} \mathrm{NO}$-derived species. Furthermore, the formation of oxidation products (e.g., RSOOH) and/or a dimerization (RS-SR) of topo II-SH groups is also possible. Such modifications of topo II-SH groups ultimately leads to inactivation and/or decrease in topo II activities and, thus, in decreased formation of SDS$\mathrm{KCl}$ precipitate (cleavable complexes), as we observed in both HT-29 and MCF-7 cancer cells in the presence of VP-16. These events together caused a significant resistance to VP-16 in these tumor cells.

It is interesting to note that we observed a small difference in the degree of VP-16 resistance between HT-29 and MCF-7 cancer cells (4-5-fold and 10-fold, respectively). While, the role of the cellular status of p53 protein in resistance is not clear at this time, we found no significant differences in DOX cytotoxicity in these cell lines following PPNO treatment, indicating that the cellular status of p53 protein may not be the only factor for cytotoxicity 
and resistance to VP-16 and the small difference in resistance observed here may simply be due to differing sensitivity of different tumor cells to the drugs.

The most interesting and somewhat surprising finding is that PPNO treatment had no significant effect on DOX-induced cleavable complex formation nor did it have any significant effects on DOX cytotoxicity in these cells lines. While the mechanisms of DOXinduced tumor cell killing are extremely complicated and various mechanisms have been reported [16, 54-56], DOX is also considered to be a topo II poison. Under conditions where both the catalytic and relaxation activity of topo II were inhibited by PPNO, resulting in significant resistance to VP-16, no effect on DOX cytotoxicity was observed in either HT-29 or MCF-7 tumor cells. This would suggest a mechanism that is independent of topo II for DOX in these cell lines in the presence of ${ }^{\circ} \mathrm{NO} /{ }^{\circ} \mathrm{NO}$-related species. Further work is being carried out to understand the mechanism(s) of DOX cytotoxicity in the presence of ${ }^{\bullet} \mathrm{NO} /{ }^{\circ} \mathrm{NO}$-generating systems.

The role of ${ }^{\bullet} \mathrm{NO} /{ }^{\bullet} \mathrm{NO}-$-related species in cancer drug resistance is not known. However, several studies suggest that increased production of ${ }^{\circ} \mathrm{NO} /{ }^{\circ} \mathrm{NO}$-related species leads to the development of drug-resistance in tumor cells via modulating the tumor angiogenesis protein, HIFa [40, 44]. ${ }^{\circ} \mathrm{NO}$ is also implicated in modulating DNA repair pathways by upregulating both p53 protein [57-61] and DNA-dependent protein kinases [62]. Furthermore, recent studies implicate inflammation as an important player in the development of aggressive and difficult-to-treat cancers [63, 64]. It has been suggested that INF $\gamma$, which induces iNOS (thus forming high amounts of ${ }^{\circ} \mathrm{NO} /{ }^{\circ} \mathrm{NO}$-related species in tumors) may be involved in the selection of more aggressive, clinically resistant tumors. In fact, higher levels of IFN $\gamma$ expression were present in patients with aggressive tumor phenotypes leading to tumor recurrence and poor survival $[65,66]$. In support, Heinecke et al. [36] have clearly shown that IFN $\gamma$ induces iNOS and IL-6 in MDA-MB-231 breast cancer cells, resulting in resistance to taxol, a clinically active drug for the treatment of breast cancers.

\subsection{Conclusions}

Studies presented here show that ${ }^{\circ} \mathrm{NO} /{ }^{\circ} \mathrm{NO}$-related species induce resistance to the topo II poison VP-16 in human tumor cells by inhibiting its catalytic and relaxation activities, most likely by nitrosating topo II a protein. However, there were no significant effects on the activity of DOX in either cell line. Our studies support the notion that expression of iNOS in human tumors or tumor microenvironments rich in ${ }^{\circ} \mathrm{NO}$ production induces significant resistance to chemotherapy in the clinic and provides a rationale for poor clinical outcomes for patients undergoing treatment with certain topo II-based therapy. It is clear from our studies that patients harboring tumors with high iNOS expression will fail to respond to therapy with certain topo-active drugs [33-35] and taxol [36] unless care is taken first to inhibit iNOS or mechanism(s) regulating ${ }^{\circ} \mathrm{NO}$ production in tumors by including specific inhibitors of iNOS, e.g., GW274150 or GW273629 [67].

\section{Acknowledgments}

We thank Dr. Ann Motten and Mrs. Mary Mason for their invaluable help in editing the manuscript. We also thank Drs. Maria Kadiiska and Thomas van't Erve for their critical evaluation of the manuscript.

Biochim Biophys Acta. Author manuscript; available in PMC 2017 July 01. 
Funding: This research was supported [in part] by the intramural research program of the National Institute of Environmental Health Sciences, NIH. Statements contained herein do not necessarily represent the statements, opinions, or conclusions of NIEHS, NIH, or the US Government.

\section{References}

1. Wang JC. DNA topoisomerases. Annu Rev Biochem. 1985; 54:665-697. [PubMed: 2992360]

2. Pommier Y, Leteurtre F, Fesen MR, Fujimori A, Bertrand R, Solary E, Kohlhagen G, Kohn KW. Cellular determinants of sensitivity and resistance to DNA topoisomerase inhibitors. Cancer Invest. 1994; 12:530-542. [PubMed: 7922710]

3. Froelich-Ammon SJ, Osheroff N. Topoisomerase poisons: harnessing the dark side of enzyme mechanism. J Biol Chem. 1995; 270:21429-21432. [PubMed: 7665550]

4. Walker JV, Nitiss JL. DNA topoisomerase II as a target for cancer chemotherapy. Cancer Invest. 2002; 20:570-589. [PubMed: 12094551]

5. Nitiss JL. Targeting DNA topoisomerase II in cancer chemotherapy. Nature reviews Cancer. 2009; 9:338-350. [PubMed: 19377506]

6. Long BH, Musial ST, Brattain MG. Comparison of cytotoxicity and DNA breakage activity of congeners of podophyllotoxin including VP16-213 and VM26: a quantitative structure-activity relationship. Biochemistry. 1984; 23:1183-1188. [PubMed: 6712942]

7. Pommier Y, Tanizawa A, Kohn KW. Mechanisms of topoisomerase I inhibition by anticancer drugs. Advances in pharmacology. 1994; 29B:73-92. [PubMed: 8996602]

8. Sinha BK. Topoisomerase inhibitors. A review of their therapeutic potential in cancer. Drugs. 1995; 49:11-19. [PubMed: 7705211]

9. Haim N, Roman J, Nemec J, Sinha BK. Peroxidative free radical formation and O-demethylation of etoposide(VP-16) and teniposide(VM-26). Biochem Biophys Res Commun. 1986; 135:215-220. [PubMed: 3006680]

10. Haim N, Nemec J, Roman J, Sinha BK. Peroxidase-catalyzed metabolism of etoposide (VP-16-213) and covalent binding of reactive intermediates to cellular macromolecules. Cancer Res. 1987; 47:5835-5840. [PubMed: 3117357]

11. Haim N, Nemec J, Roman J, Sinha BK. In vitro metabolism of etoposide (VP-16-213) by liver microsomes and irreversible binding of reactive intermediates to microsomal proteins. Biochemical pharmacology. 1987; 36:527-536. [PubMed: 3030329]

12. Endicott JA, Ling V. The biochemistry of P-glycoprotein-mediated multidrug resistance. Annu Rev Biochem. 1989; 58:137-171. [PubMed: 2570548]

13. Chin KV, Pastan I, Gottesman MM. Function and regulation of the human multidrug resistance gene. Advances in cancer research. 1993; 60:157-180. [PubMed: 8417499]

14. Beck WT, Danks MK, Wolverton JS, Kim R, Chen M. Drug resistance associated with altered DNA topoisomerase II. Advances in enzyme regulation. 1993; 33:113-127. [PubMed: 8395133]

15. Burgess DJ, Doles J, Zender L, Xue W, Ma B, McCombie WR, Hannon GJ, Lowe SW, Hemann MT. Topoisomerase levels determine chemotherapy response in vitro and in vivo. Proc Natl Acad Sci U S A. 2008; 105:9053-9058. [PubMed: 18574145]

16. Sinha BK. Free radicals in anticancer drug pharmacology. Chemico-biological interactions. 1989; 69:293-317. [PubMed: 2659197]

17. Fridman JS, Lowe SW. Control of apoptosis by p53. Oncogene. 2003; 22:9030-9040. [PubMed: 14663481]

18. Prosperi E, Sala E, Negri C, Oliani C, Supino R, Astraldi Ricotti GB, Bottiroli G. Topoisomerase II alpha and beta in human tumor cells grown in vitro and in vivo. Anticancer Res. 1992; 12:20932099. [PubMed: 1338275]

19. Austin CA, Marsh KL. Eukaryotic DNA topoisomerase II beta. BioEssays: news and reviews in molecular cellular and developmental biology. 1998; 20:215-226.

20. Wang Y, Zhou R, Liliemark J, Gruber A, Lindemalm S, Albertioni F, Liliemark E. In vitro topo II-DNA complex accumulation and cytotoxicity of etoposide in leukaemic cells from patients with acute myelogenous and chronic lymphocytic leukaemia. Leukemia research. 2001; 25:133-140. [PubMed: 11166828] 
21. Deweese JE, Osheroff N. The DNA cleavage reaction of topoisomerase II: wolf in sheep's clothing. Nucleic acids research. 2009; 37:738-748. [PubMed: 19042970]

22. Felix CA, Hosler MR, Slater DJ, Parker RI, Masterson M, Whitlock JA, Rebbeck TR, Nowell PC, Lange BJ. MLL genomic breakpoint distribution within the breakpoint cluster region in de novo leukemia in children. Journal of pediatric hematology/oncology. 1998; 20:299-308. [PubMed: 9703001]

23. Nitiss JL. DNA topoisomerase II and its growing repertoire of biological functions. Nature reviews Cancer. 2009; 9:327-337. [PubMed: 19377505]

24. Cowell IG, Sondka Z, Smith K, Lee KC, Manville CM, Sidorczuk-Lesthuruge M, Rance HA, Padget K, Jackson GH, Adachi N, Austin CA. Model for MLL translocations in therapy-related leukemia involving topoisomerase IIbeta-mediated DNA strand breaks and gene proximity. Proc Natl Acad Sci U S A. 2012; 109:8989-8994. [PubMed: 22615413]

25. Alderton WK, Cooper CE, Knowles RG. Nitric oxide synthases: structure, function and inhibition. The Biochemical journal. 2001; 357:593-615. [PubMed: 11463332]

26. Xu W, Liu LZ, Loizidou M, Ahmed M, Charles IG. The role of nitric oxide in cancer. Cell Res. 2002; 12:311-320. [PubMed: 12528889]

27. Ridnour LA, Thomas DD, Donzelli S, Espey MG, Roberts DD, Wink DA, Isenberg JS. The biphasic nature of nitric oxide responses in tumor biology. Antioxid Redox Signal. 2006; 8:13291337. [PubMed: 16910780]

28. Napoli C, Paolisso G, Casamassimi A, Al-Omran M, Barbieri M, Sommese L, Infante T, Ignarro LJ. Effects of nitric oxide on cell proliferation: novel insights. J Am Coll Cardiol. 2013; 62:89-95. [PubMed: 23665095]

29. Crowell JA, Steele VE, Sigman CC, Fay JR. Is inducible nitric oxide synthase a target for chemoprevention? Molecular cancer therapeutics. 2003; 2:815-823. [PubMed: 12939472]

30. Loibl S, Buck A, Strank C, von Minckwitz G, Roller M, Sinn HP, Schini-Kerth V, Solbach C, Strebhardt K, Kaufmann M. The role of early expression of inducible nitric oxide synthase in human breast cancer. Eur J Cancer. 2005; 41:265-271. [PubMed: 15661552]

31. Wang L, Xie K. Nitric oxide and pancreatic cancer pathogenesis, prevention, and treatment. Current pharmaceutical design. 2010; 16:421-427. [PubMed: 20236070]

32. Glynn SA, Boersma BJ, Dorsey TH, Yi M, Yfantis HG, Ridnour LA, Martin DN, Switzer CH, Hudson RS, Wink DA, Lee DH, Stephens RM, Ambs S. Increased NOS2 predicts poor survival in estrogen receptor-negative breast cancer patients. J Clin Invest. 2010; 120:3843-3854. [PubMed: 20978357]

33. Sinha BK, Bhattacharjee S, Chatterjee S, Jiang J, Motten AG, Kumar A, Espey MG, Mason RP. Role of nitric oxide in the chemistry and anticancer activity of etoposide (VP-16,213). Chem Res Toxicol. 2013; 26:379-387. [PubMed: 23402364]

34. Sinha BK, Kumar A, Bhattacharjee S, Espey MG, Mason RP. Effect of nitric oxide on the anticancer activity of the topoisomerase-active drugs etoposide and adriamycin in human melanoma cells. J Pharmacol Exp Ther. 2013; 347:607-614. [PubMed: 24049059]

35. Sharma NK, Kumar A, Kumari A, Tokar EJ, Waalkes MP, Bortner CD, Williams J, Ehrenshaft M, Mason RP, Sinha BK. Nitric Oxide Down-Regulates Topoisomerase I and Induces Camptothecin Resistance in Human Breast MCF-7 Tumor Cells. PloS one. 2015; 10:e0141897. [PubMed: 26540186]

36. Heinecke JL, Ridnour LA, Cheng RY, Switzer CH, Lizardo MM, Khanna C, Glynn SA, Hussain SP, Young HA, Ambs S, Wink DA. Tumor microenvironment-based feed-forward regulation of NOS2 in breast cancer progression. Proc Natl Acad Sci U S A. 2014; 111:6323-6328. [PubMed: 24733928]

37. Ridnour LA, Thomas DD, Mancardi D, Espey MG, Miranda KM, Paolocci N, Feelisch M, Fukuto J, Wink DA. The chemistry of nitrosative stress induced by nitric oxide and reactive nitrogen oxide species. Putting perspective on stressful biological situations. Biological chemistry. 2004; 385:110. [PubMed: 14977040]

38. Lancaster JR Jr. Nitroxidative, nitrosative, and nitrative stress: kinetic predictions of reactive nitrogen species chemistry under biological conditions. Chem Res Toxicol. 2006; 19:1160-1174. [PubMed: 16978020] 
39. Wang YT, Piyankarage SC, Williams DL, Thatcher GR. Proteomic profiling of nitrosative stress: protein S-oxidation accompanies S-nitrosylation. ACS chemical biology. 2014; 9:821-830. [PubMed: 24397869]

40. Zhou J, Schmid T, Brune B. HIF-1alpha and p53 as targets of NO in affecting cell proliferation, death and adaptation. Curr Mol Med. 2004; 4:741-751. [PubMed: 15579021]

41. Chanvorachote P, Nimmannit U, Stehlik C, Wang L, Jiang BH, Ongpipatanakul B, Rojanasakul Y. Nitric oxide regulates cell sensitivity to cisplatin-induced apoptosis through S-nitrosylation and inhibition of Bcl-2 ubiquitination. Cancer Res. 2006; 66:6353-6360. [PubMed: 16778213]

42. Li F, Sonveaux P, Rabbani ZN, Liu S, Yan B, Huang Q, Vujaskovic Z, Dewhirst MW, Li CY. Regulation of HIF-1alpha stability through S-nitrosylation. Mol Cell. 2007; 26:63-74. [PubMed: 17434127]

43. Sikora AG, Gelbard A, Davies MA, Sano D, Ekmekcioglu S, Kwon J, Hailemichael Y, Jayaraman P, Myers JN, Grimm EA. Targeted inhibition of inducible nitric oxide synthase inhibits growth of human melanoma in vivo and synergizes with chemotherapy. Clinical cancer research. 2010; 16:1834-1844. [PubMed: 20215556]

44. Chowdhury R, Godoy LC, Thiantanawat A, Trudel LJ, Deen WM, Wogan GN. Nitric oxide produced endogenously is responsible for hypoxia-induced HIF-1alpha stabilization in colon carcinoma cells. Chem Res Toxicol. 2012; 25:2194-2202. [PubMed: 22971010]

45. Godoy LC, Anderson CT, Chowdhury R, Trudel LJ, Wogan GN. Endogenously produced nitric oxide mitigates sensitivity of melanoma cells to cisplatin. Proc Natl Acad Sci U S A. 2012; 109:20373-20378. [PubMed: 23185001]

46. Hasinoff BB, Wu X, Krokhin OV, Ens W, Standing KG, Nitiss JL, Sivaram T, Giorgianni A, Yang S, Jiang Y, Yalowich JC. Biochemical and proteomics approaches to characterize topoisomerase IIalpha cysteines and DNA as targets responsible for cisplatin-induced inhibition of topoisomerase IIalpha. Mol Pharmacol. 2005; 67:937-947. [PubMed: 15602006]

47. Yamazaki H, Dilworth A, Myers CE, Sinha BK. Suramin inhibits DNA damage in human prostate cancer cells treated with topoisomerase inhibitors in vitro. The Prostate. 1993; 23:25-36. [PubMed: 8393191]

48. Nitiss, JL.; Soans, E.; Rogojina, A.; Seth, A.; Mishina, M. Topoisomerase assays. In: Enna, SJ., editor. Current protocols in pharmacology. Vol. 3. 2012.

49. Liu LF, Rowe TC, Yang L, Tewey KM, Chen GL. Cleavage of DNA by mammalian DNA topoisomerase II. J Biol Chem. 1983; 258:15365-15370. [PubMed: 6317692]

50. Tokar EJ, Person RJ, Sun Y, Perantoni AO, Waalkes MP. Chronic exposure of renal stem cells to inorganic arsenic induces a cancer phenotype. Chem Res Toxicol. 2013; 26:96-105. [PubMed: 23137061]

51. Jensen LH, Renodon-Corniere A, Wessel I, Langer SW, Sokilde B, Carstensen EV, Sehested M, Jensen PB. Maleimide is a potent inhibitor of topoisomerase II in vitro and in vivo: a new mode of catalytic inhibition. Mol Pharmacol. 2002; 61:1235-1243. [PubMed: 11961142]

52. Wang H, Mao Y, Chen AY, Zhou N, LaVoie EJ, Liu LF. Stimulation of topoisomerase II-mediated DNA damage via a mechanism involving protein thiolation. Biochemistry. 2001; 40:3316-3323. [PubMed: 11258951]

53. Gantchev TG, Hunting DJ. The ortho-quinone metabolite of the anticancer drug etoposide (VP-16) is a potent inhibitor of the topoisomerase II/DNA cleavable complex. Mol Pharmacol. 1998; 53:422-428. [PubMed: 9495807]

54. Sinha BK, Mimnaugh EG. Free radicals and anticancer drug resistance: oxygen free radicals in the mechanisms of drug cytotoxicity and resistance by certain tumors. Free radical biology \& medicine. 1990; 8:567-581. [PubMed: 2113883]

55. Myers, CE.; Mimnaugh, EG.; Yeh, GC.; Sinha, BK. Biochemical Mechanisms of Tumor Cell Kill by the Anthracyclines. In: Lown, JW., editor. Anthracycline and Anthracenedione-based Anticancer Agents. Elsevier; 1988. p. 527-569.Place Published

56. Sinha BK, Mason RP. Is Metabolic Activation of Topoisomerase II Poisons Important In The Mechanism Of Cytotoxicity? J Drug Metab Toxicol. 2015; 6:1-8. 
57. Calmels S, Hainaut $\mathrm{P}$, Ohshima $\mathrm{H}$. Nitric oxide induces conformational and functional modifications of wild-type p53 tumor suppressor protein. Cancer Res. 1997; 57:3365-3369. [PubMed: 9269997]

58. Chazotte-Aubert L, Hainaut P, Ohshima H. Nitric oxide nitrates tyrosine residues of tumorsuppressor p53 protein in MCF-7 cells. Biochem Biophys Res Commun. 2000; 267:609-613. [PubMed: 10631110]

59. Jaiswal M, LaRusso NF, Burgart LJ, Gores GJ. Inflammatory cytokines induce DNA damage and inhibit DNA repair in cholangiocarcinoma cells by a nitric oxide-dependent mechanism. Cancer Res. 2000; 60:184-190. [PubMed: 10646872]

60. Jaiswal M, LaRusso NF, Nishioka N, Nakabeppu Y, Gores GJ. Human Ogg1, a protein involved in the repair of 8-oxoguanine, is inhibited by nitric oxide. Cancer Res. 2001; 61:6388-6393. [PubMed: 11522631]

61. Liu L, Xu W. The Role of Nitric Oxide in Cancer Cell DNA Repair, Hypoxia Adaptation and Drug Resistance. Single Cell Biol. 2013; 2:2.

62. Xu W, Liu L, Smith GC, Charlesl G. Nitric oxide upregulates expression of DNA-PKcs to protect cells from DNA-damaging anti-tumour agents. Nat Cell Biol. 2000; 2:339-345. [PubMed: 10854324]

63. Shih JY, Yuan A, Chen JJW, Yang PC. Tumor-associated macrophage: its role in cancer invasion and metastasis. J Cancer Mol. 2006; 2:101-106.

64. Lewis CE, Pollard JW. Distinct role of macrophages in different tumor microenvironments. Cancer Res. 2006; 66:605-612. [PubMed: 16423985]

65. Weichselbaum RR, Ishwaran H, Yoon T, Nuyten DS, Baker SW, Khodarev N, Su AW, Shaikh AY, Roach P, Kreike B, Roizman B, Bergh J, Pawitan Y, van de Vijver MJ, Minn AJ. An interferonrelated gene signature for DNA damage resistance is a predictive marker for chemotherapy and radiation for breast cancer. Proc Natl Acad Sci U S A. 2008; 105:18490-18495. [PubMed: 19001271]

66. Zaidi MR, Merlino G. The two faces of interferon-gamma in cancer. Clin Cancer Res. 2011; 17:6118-6124. [PubMed: 21705455]

67. Alderton WK, Angell AD, Craig C, Dawson J, Garvey E, Moncada S, Monkhouse J, Rees D, Russell LJ, Russell RJ, Schwartz S, Waslidge N, Knowles RG. GW274150 and GW273629 are potent and highly selective inhibitors of inducible nitric oxide synthase in vitro and in vivo. $\mathrm{Br} \mathrm{J}$ Pharmacol. 2005; 145:301-312. [PubMed: 15778742] 


\section{Highlights}

Nitric oxide induces S-nitrosation of topoisomerase II in human tumor cells

Nitric oxide significantly inhibits topo II functions in vitro and in tumor cells.

Nitric Oxide induces resistance to etoposide and XK469, topo II-poisons. 

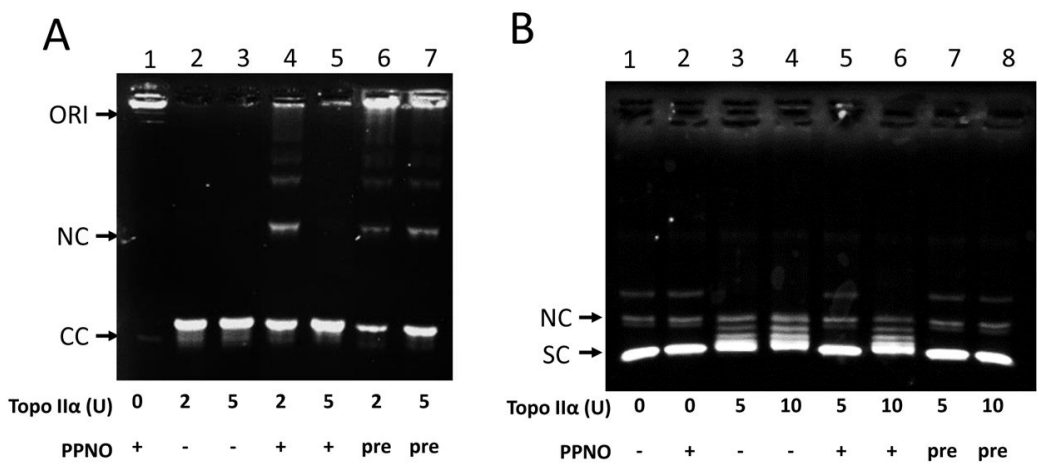

Fig. 1.

Effect of PPNO $(100 \mu \mathrm{M})$ on Topoisomerase IIa. The decatenation (A) assay was carried out using kDNA as described in the Methods section. Lane 1, control DNA with 100 $\mu$ M PPNO; lanes 2 and 3 with topo IIa ( 2 and 5 units, respectively); lanes 4 and 5, with topo IIa ( 2 and

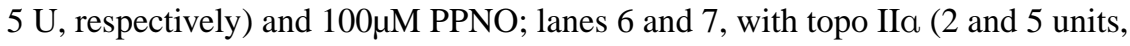
respectively) preincubated with $100 \mu \mathrm{M}$ PPNO (10 $\mathrm{min})$ before adding DNA. DNA relaxation (B) assay using pHOT1 DNA was carried out as described in the Methods section.

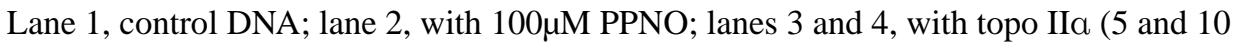
units, respectively); lanes 5 and 6, with topo IIa (5 and 10 units, respectively) and $100 \mu \mathrm{M}$ PPNO; lanes 7 and 8, with topo IIa (5 and 10 units, respectively) preincubated with $100 \mu \mathrm{M}$ PPNO (10 min) before adding DNA. NC, nicked open circular kDNA; CC, closed circular kDNA; ORI, origin. 
A
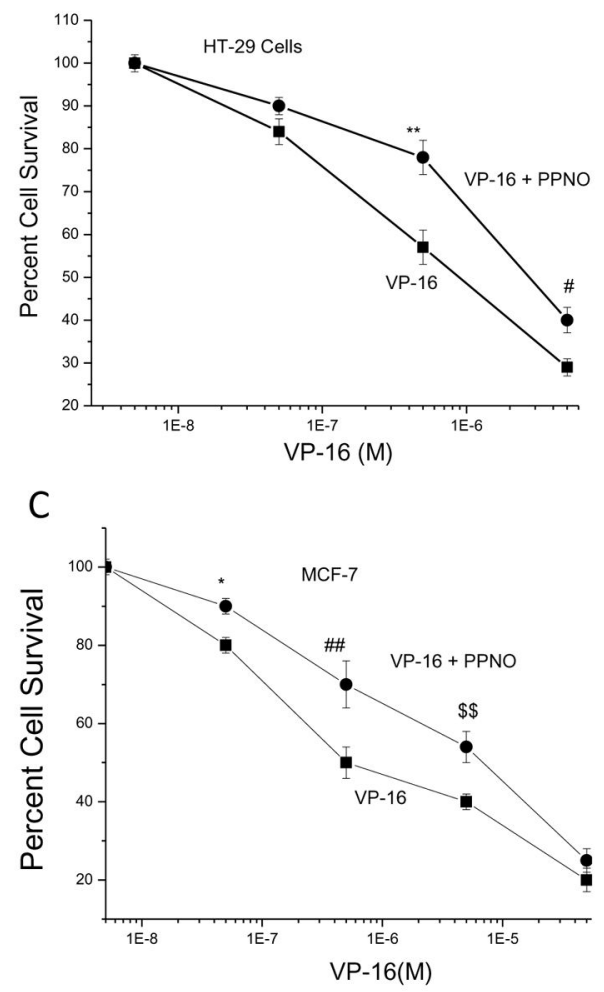

B
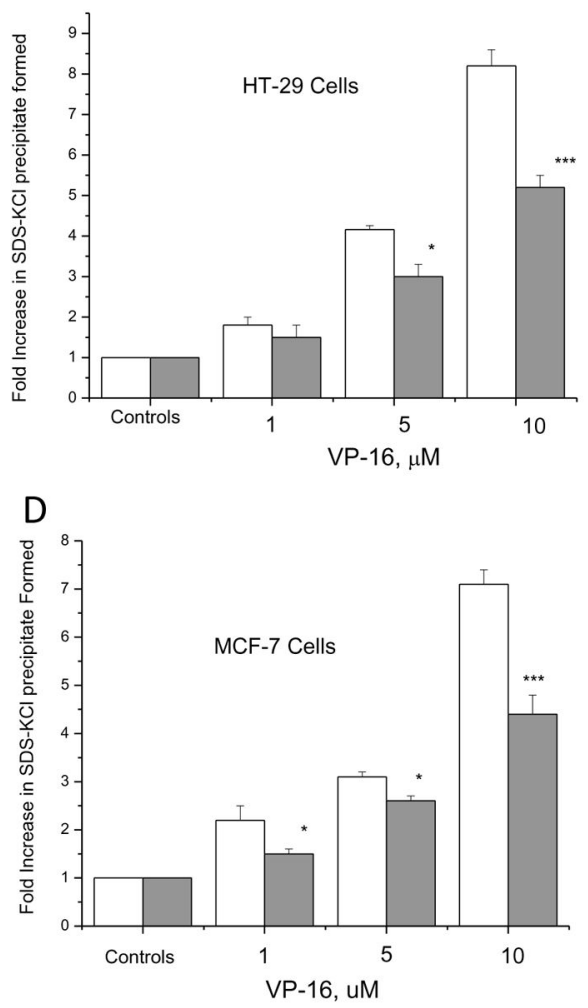

Fig. 2.

Cytotoxicity of VP-16 in HT-29 cells (A) and MCF-7 (C) using a cell count-based method as described in the Methods section. Cells were seeded in 6-well plates in triplicate and allowed to attach for $18 \mathrm{~h}$. PPNO $(100 \mu \mathrm{M})$ treatment was carried out in a medium containing 1\% FBS without antibiotics for $6 \mathrm{~h}$. VP-16 alone (ם-口); VP-16 in cells treated with PPNO (-). Formation of cleavage complexes in HT-29 (B) and MCF-7 cells (D) in the presence of VP-16 ( $\square$ ) and VP-16 with PPNO ( $\mathbf{\square})$. Cells were treated with $100 \mu \mathrm{M}$ PPNO for $6 \mathrm{~h}$ before treating with VP-16 for $1 \mathrm{~h}$ in the complete medium and carrying out $\mathrm{SDS}-\mathrm{KCl}$ precipitation assays as described in the Methods section. Data represent at least three independent experiments. $* * *,{ }^{* *}$ and ${ }^{*}$ p values $\leq 0.001,0.005$ and 0.05 , respectively, compared with concentration-matched samples. Also, \#\#, \$\$, and \# p values $\leq 0.001,0.005$ and 0.05 , respectively, compared with concentration-matched samples. 
A

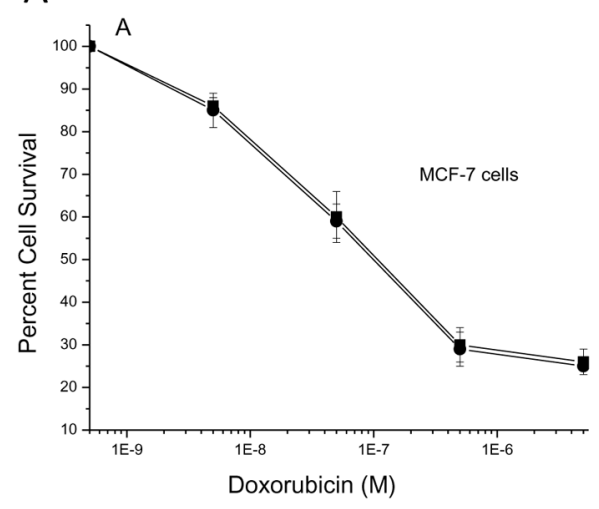

C

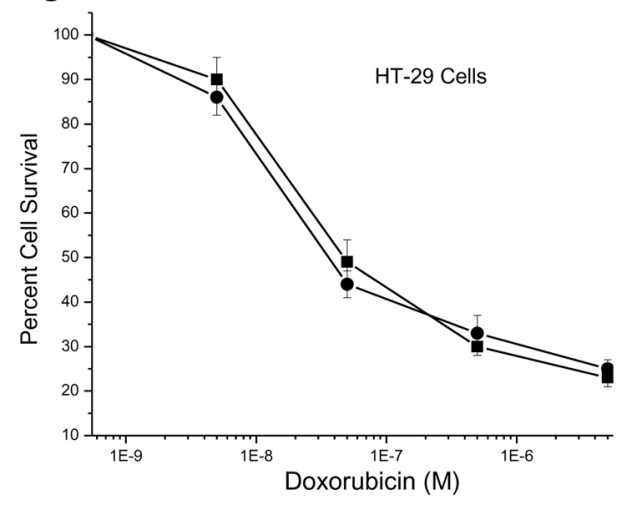

B

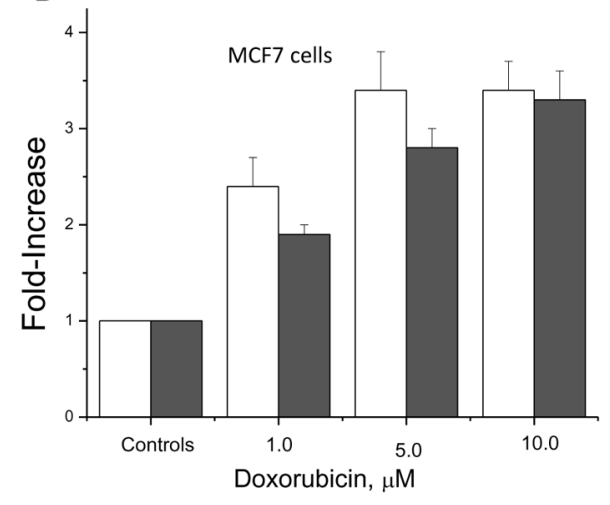

D

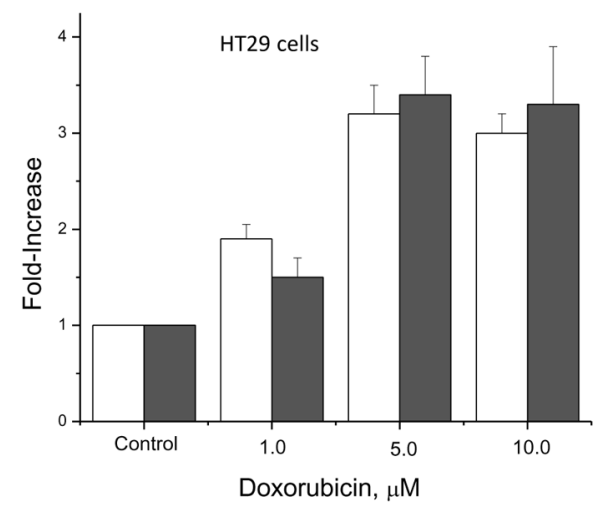

Fig. 3.

Cytotoxicity of DOX in MCF-7 (A) and HT-29 cells (C) using a cell count-based method as described in the Methods section. DOX alone (ם-ם); DOX in cells treated with PPNO

O). Formation of cleavable complexes in MCF-7 (B) and HT-29 cells (D) in the presence of DOX $(\square)$ and DOX with PPNO ( $\square)$. Cells were treated with $100 \mu \mathrm{M}$ PPNO for $6 \mathrm{~h}$ before treating with DOX for $1 \mathrm{~h}$ in the complete medium and carrying out SDS- $\mathrm{KCl}$ precipitation assays as described in the Methods section. Data represent at least three independent experiments.

Biochim Biophys Acta. Author manuscript; available in PMC 2017 July 01. 

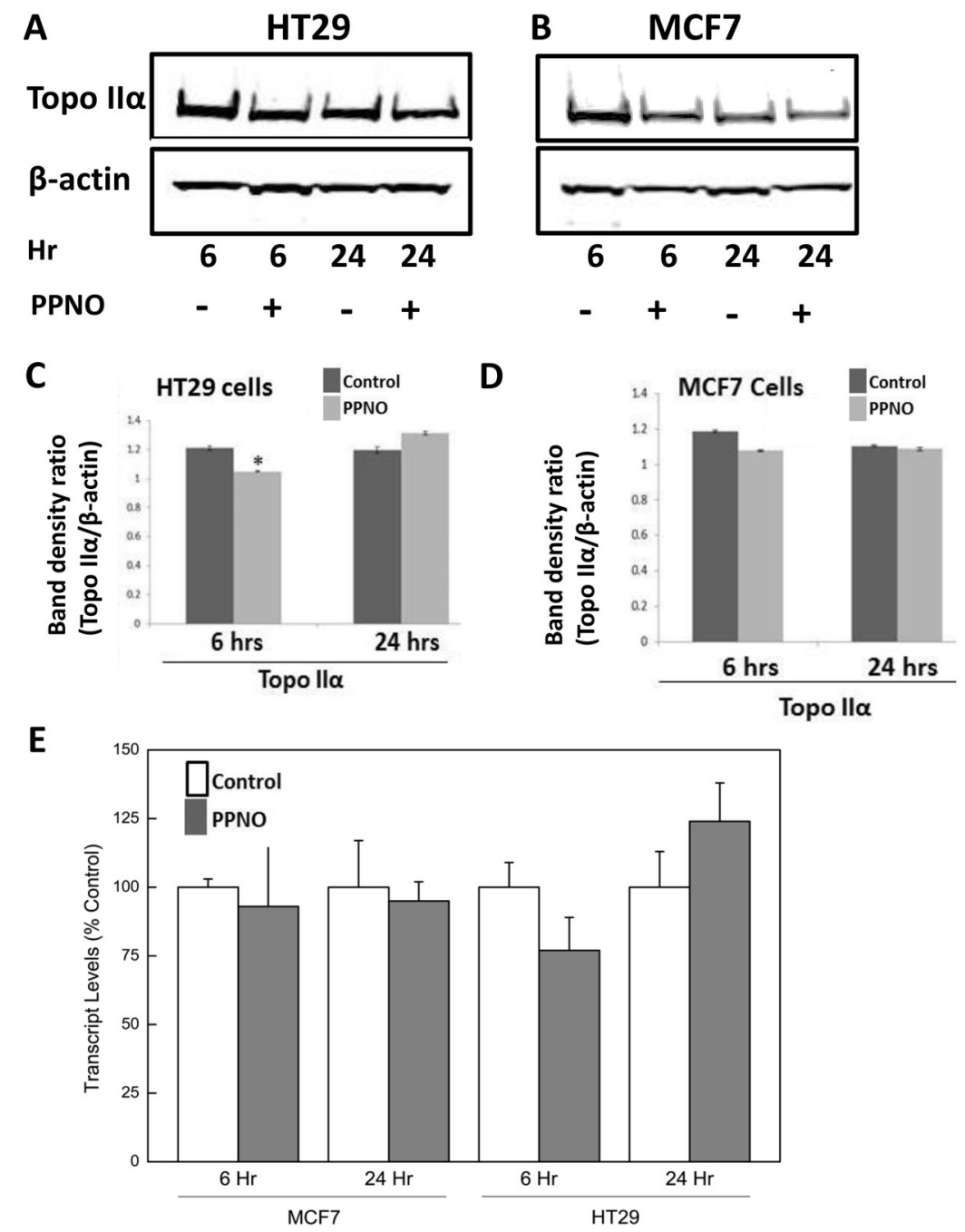

Fig. 4.

Effects of ${ }^{\bullet}$ NO on topo II protein levels in HT-29 (A) and MCF-7 cells (B). Cells were treated with $100 \mu \mathrm{M}$ PPNO for various times as described in the Methods section. Cells were collected, lysed and analyzed by Western blots for topo IIa. Quantification of the topo IIa protein in HT-29 cells (C) and MCF-7 Cells (D). Transcript levels (mRNA) of the topo II gene (E) in HT-29 and MCF-7 cells. Transcript levels were determined as described in the Methods section using actin as the control. Data represent at least three independent experiments. ${ }^{*}$ p values $\leq 0.05$, compared with time-matched samples. 
A

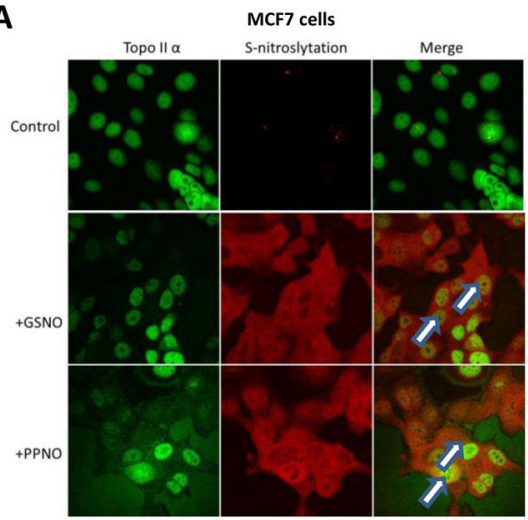

B

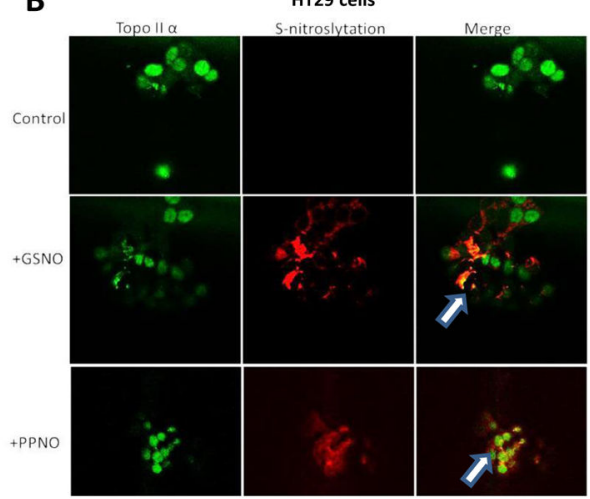

Fig. 5.

S-Nitrosation of -SH groups of topoisomerase IIa in MCF-7 cells (A) and HT-29 cells (B) by PPNO $(100 \mu \mathrm{M})$ and GSNO $(500 \mu \mathrm{M})$. Cells were treated with NO-donors for $18 \mathrm{~h}$ as described in the methods section and processed for confocal microscopy studies. Colocalized S-nitrosated topo IIa proteins in MCF-7 and HT-29 cells are indicated by arrow heads. 